\title{
ANALISIS PEMIKIRAN MUSDAH MULIA TENTANG WALI NIKAH DAN RELEVANSINYA TERHADAP PEMBARUAN HUKUM KELUARGA DI INDONESIA
}

\author{
Siti Hafshah Syahanti \\ PengadilanAgama Maninjau, sitihafshahsy@gmail.com
}

Arsal

IAIN Bukittinggi, arsalsal@yahoo.com

Edi Rosman

LAIN Bukittinggi,edirosmanmalin@yahoo.com

\begin{abstract}
The discussion of marriage guardian is one of the pillars that must exist in a marriage, illegitimate marriage without the presence of a guardian. The Compilation of Islamic Law (KHI) as the law governing Muslim marriages in Indonesia requires guardians as a legal condition of marriage (articles 14 and 19). However, on the other hand, one of the Muslim intellectuals, Siti Musdah Mulia, stated an opposing idea, that guardians are not included in the pillars of marriage. The results showed that the Musdah Mulia thinking generally led to the typology of liberal Islamic thought. Specifically on the issue of the absence of guardians in marriage, Musdah's opinions are not too contrary to the text; Musdah's attention to gender places a substantial portion in establishing the law; and the Musdah idea is not only channeled in the form of thought alone but also poured into the form of a legal regulation draft (CLD-KHI) so that the law applies comprehensively and can be applied clearly and can achieve justice and social benefit in the midst of the people. Then based on this, a specific typology of Musdah Mulia's thought was obtained about the absence of guardians in the marriage harmony leading to progressive Islamic thought. And Musdah Mulia's ideas about the lack of marriage guardians have sufficient relevance to the renewal of Islamic family law in Indonesia.
\end{abstract}

Keywords: Musdah Mulia, Wali Nikah, Islamic Family Law Renewal.

\begin{abstract}
Abstrak
Pembahasan wali nikah merupakan salah satu rukun yang harus ada dalam suatu perkawinan, tidak sah perkawinan tanpa kehadiran wali. Kompilasi Hukum Islam (KHI) sebagai bukum yang mengatur perkawinan umat Islam di Indonesia mensyaratkan wali sebagai syarat sab pernikaban( pasal 14 dan 19). Namun, disisi lain salah seorang intelektual muslim, Siti Musdah Mulia, menyatakan sebuah gagasan yang berlawanan, bahwa wali bukanlah termasuk rukun nikah. Hasil penelitian menunjukkan bahwa pemikiran Musdah Mulia secara umum mengarah kepada tipologi pemikiran Islam liberal. Khusus tentang persoalan ketiadaan wali dalam pernikahan, pemikiran Musdah tidak terlalu bertentangan dengan nash; perbatian Musdah terbadap gender menempatkan porsi yang sangat besar dalam menetapkan bukum tersebut; dan ide Musdah tidak hanya disalurkan dalam bentuk, pemikiran semata, tetapi juga dituangkan ke dalam bentuk rancangan peraturan bukum (CLD-KHI) agar bukum berlaku menyeluruh dan dapat diaplikasikan secara nyata serta dapat mencapai keadilan dan kemaslabatan sosial di tengahtengah umat. Maka berdasarkan hal tersebut diperoleh tipologi pemikiran Musdah Mulia khusus tentang ketiadaan wali dalam rukun nikah mengarah kepada pemikiran Islam progresif. Pemikiran Musdah Mulia tentang ketiadaan wali nikah memiliki relevansi yang cukup dengan pembaruan bukum keluarga Islam di Indonesia.
\end{abstract}

Kata Kunci: Musdah Mulia, Wali Nikah, Pembaruan Hukum Keluarga Islam. 


\section{PENDAHULUAN}

Hadirnya Kompilasi Hukum Islam (KHI) di Indonesia bertujuan untuk menyiapkan pedoman yang seragam (unikatif) bagi Hakim Pengadilan Agama dan menjadi hukum positif yang wajib dipatuhi oleh seluruh bangsa Indonesia yang beragama Islam. ${ }^{1}$ Kumunculan produk hukum tersebut merupakan respon bagi perkembangan zaman yang berdampak terhadap perubahan hukum. Seperti halnya KHI yang sebelumnya, oleh sebagian kalangan sudah dipandang cukup mapan untuk menampung semua aspirasi masyarakat dan menampung persoalanpersoalan baru yang muncul. Sementara menurut sebagian golongan belum cukup menanggapi persoalan yang ada. Musdah Mulia juga termasuk aktivis Pengarusutamaan Gender (PUG) yang menilai bahwa pasal-pasal yang termuat di dalam KHI (telah berjalan hampir 26 tahun) masih mengandung bias gender. Tim ini dipelopori oleh Musdah Mulia berkerja bersama 11 orang ditambah 16 orang kontributor, yang merumuskan hukum tandingan bagi KHI yang mereka sebut sebagai Counter Legal Draft Kompilasi Hukum Islam (CLD-KHI). ${ }^{2}$

Musdah Mulia menilai ada beberapa hal yang patut direvisi untuk merelevansikan pasal- pasal yang ada dalam KHI dengan kondisi masyarakat muslim. Salah satu usulan revisi pada Pasal $14 \mathrm{KHI}$ tentang keharusan adanya wali di dalam rukun pernikahan. Padahal keberadaan wali dalam akad nikah adalah suatu yang mesti dan tidak sah perkawinan tanpa wali, begitu pendapat jumhur ulama. ${ }^{3}$ Mayoritas ulama fikih berpendapat bahwa di antara rukun nikah

1 Ahmad Rofiq, Hukum Islam di Indonesia, (Jakarta: PT. RajaGrafindo Persada, 2003), 43

2 Umi Sumbulah, Ketentuan Perkawinan dalam KHI dan Implikasinya bagi Fiqh Mu'asyarah, (Malang: UIN Malang), 56.

3 Amir Syarifuddin, Hukum Perkwainan Islam di Indonesia; Antara Figh Munakahat dan Undang-Undang Perkawinan. (Jakarta: Kecana, 2011), 69 adalah wali, yaitu seorang perempuan tidak sah menikahkan dirinya sendiri, karena yang berhak mengucapkan ijab adalah wali. Hal ini berbeda dengan laki-laki yang dapat menikahkan dirinya sendiri. ${ }^{4}$ Apabila hal ini dikaitkan dengan penjelasan sebelumnya tentang usulan revisi dalam CLD-KHI tentang peniadaan wali dalam rukun nikah, maka ini menjadi salah satu polemik yang mesti dikaji dalam lingkup pembaruan hukum keluarga Islam di Indonesia khususnya.

Pembahasan mengenai wali ini memang telah diurai oleh para ulama terdahulu dan sepintas terlihat ada persamaan antara pendapat Musdah Mulia dengan gagasan Imam Abu Hanifah., bahwa seorang perempuan dewasa yang menikah tanpa wali, maka perkawinannya adalah sah. Meskipun begitu menurut penulis gagasan yang telah dipaparkan oleh Musdah Mulia baru-baru ini masih layak untuk diteliti lebih lanjut, ada beberapa alasan kenapa topik ini layak untuk diteliti, yaitu:

Rentang waktu atau zaman yang membatasi antara Imam Abu Hanifah dan Musdah Mulia cukup jauh, tidak tertutup kemungkinan ada perbedaan mengenai apa yang menjadi dalil bagi masing-masing tokoh tersebut perihal ketiadaan wali dalam rukun nikah.

Musdah Mulia merupakan seorang tokoh yang terkesan antimainstream. Ia berani berpendapat beda dengan mainstream fikih yang telah dirumuskan oleh ulama-ulama sebelumnya. Sementara bagi Musdah Mulia, wali nikah menduduki bagian yang sangat penting dalam pelaksanaan perkawinan, yaitu rukun nikah.

Musdah Mulia disamping seorang yang aktif dan punya popularitas yang cukup luas, dia juga intens dalam melakukan kajian-kajian tentang pembaruan pemikiran di berbagai

4 Tutik Hamidah, Fiqh Perempuan Berwawasan Keadilan Gender, (Malang: UIN-Maliki Press, 2011), 93. 
forum, baik skala nasional maupun internasional.

Berangkat dari wacana di atas, tulisan ini bertujuan untuk menggambarkan bagaimana tipologi pemikiran Musdah Mulia tentang ketiadaan wali nikah dan bagaimana relevansinya terhadap pembaruan hukum keluarga Islam di Indonesia.

\section{WALI NIKAH}

Dalam pernikahan wali merupakan seseorang yang bertindak atas nama mempelai perempuan dalam suatu akad nikah. Akad nikah dilakukan oleh dua pihak, yaitu pihak laki-laki yang dilakukan oleh mempelai laki-laki itu sendiri dan pihak perempuan yang dilakukan oleh walinya. ${ }^{5}$ Adapun syarat wali yang telah disepakati oleh ulama ada dua, yaitu kamal abliyah (baligh, berakal dan merdeka), serta adanya kesamaan agama antara yang mewakilkan dan diwakilkan. ${ }^{6}$

Syarat lain berkaitan dengan wali yang menjadi perdebatan fuqaba, yaitu:

1. Laki-laki, ini pendapat jumhur fukaha selain mazhab Hanafi, mazhab ini berpendapat bahwa seorang perempuan yang baligh dan berakal memiliki kekuasaan untuk mengawinkan orang yang diwakilkan oleh orang lain kepadanya. ${ }^{7}$

2. Adil, yaitu kelurusan agama dengan melaksanakan berbagai kewajiban agama serta mencegah berbagai dosa besar dan tidak bersikeras pada perbuatan dosa kecil. Ini adalah syarat menurut mazhab Syafie $i$ dan Hambali. Sementara mazhab Hanafi dan Maliki berpendapat bahwa keadilan bukanlah syarat wali. ${ }^{8}$ Menurut Imam Abu Hanifah, bagi wali yang penting bukanlah laki-laki dan ketaatannya, tetapi

\footnotetext{
${ }^{5}$ Amir Syarifuddin, Hukum ..., 69

6 Shafra, Fikih Munakahat I, (Bukittinggi: STAIN Bukittinggi Press, 2006), 114

7 Wahbah al-Zuhaili, al-Figh al-Islam wa Adillatubu, Jilid VII, (Beirut: Dar al-Fikr, 1989), 196

8 Ibid.
}

kepandaiannya memilih jodoh yang tepat bagi perempuan di bawah perwaliannya.

Kedudukan Wali bagi mempelai yang masih kecil baik laki-laki dan perempuan, ulama sepakat mendudukkan wali sebagai rukun pernikahan, karena mempelai yang masih kecil tidak dapat melakukan akad dengan sendirinya, maka dari itu dilakukan oleh walinya. ${ }^{10}$ Namun terhadap perempuan yang telah dewasa baik janda atau masih perawan, para ulama fikih berbeda pendapat tentang keabsahan pernikahannya. Hal tersebut dikarenakan oleh tidak adanya dalil yang pasti yang dapat dijadikan rujukan sehingga masing- masing kelompok ulama punya alasan dalil tekstual dalil dan alasan logika. ${ }^{11}$

Secara masyhur, yayoritas ulama fikih berpendapat bahwa diantara rukun nikah adalah wali, yaitu seorang perempuan tidak sah menikahkan dirinya sendiri, karena yang berhak mengucapkan ijab adalah wali. Hal ini berbeda dengan laki-laki yang dapat menikahkan dirinya sendiri.

Terdapat dua pandangan mengenai wali dalam pernikahan. Pertama, Jumhur ulama berkata bahwa pernikahan terlaksana dengan ungkapan dari kalangan perempuan. Jika ada seorang perempuan menikahkan dirinya sendiri atau menikahkan orang lain atau mewakilkan hak dirinya kepada orang lain untuk menikahkannya sekalipun dengan izin walinya maka pernikahannya tidaklah sah. Itu karena syarat akad nikah belum terpenuhi, yaitu keberadaan seorang wali. Kedua, pendapat Imam Abu Hanifah dan Abu Yusuf dalam riwayat yang jelas manyatakan bahwa pernikahan seorang perempuan yang baligh lagi berakal, terlaksana dengan keridhaanya,

9 Sulaiman al-Faifi, Ringkasan Fikih Sunah, terjemahan dari al-Wajiizu fi Fiqhi al-Sunnah oleh Abdul Majid, (Jakarta: Ummul Qura, 2014), 484

10 Amir Syarifuddin, Hukum ..., 69

11 Tim Sinergi, Tatanan Berkeluarga dalam Islam, (Jakarta: Lembaga Kajian Ketahanan Keluarga Indonesia [LK3], 2015), 154 
sekalipun tanpa seorang wali, baik gadis maupun janda. Sedangkan menurut Muhammad al-Syaibani pernikahan tersebut terlaksana namun manquf. ${ }^{12}$

Sementara itu, persoalan wali nikah dalam hukum positif telah dimuat secara jelas pada pasal 14 KHI, bahwa untuk melaksanakan perkawinan harus ada: a) calon suami; b) calon isteri; c) wali nikah; d) dua orang saksi; dan e) ijab dan kabul. Keseluruhan rukun tersebut mengikuti pendapat mazhab Syafie $i$, sebagaimana sumber rujukan yang digunakan dalam penyusunan KHI dari awal sampai akhir. Berkenaan dengan syarat menjadi wali nikah, di dalam KHI pasal 20 ayat (1) menyebutkan, yang bertindak sebagai wali nikah ialah seorang laki-laki yang memenuhi syarat hukum Islam yakni muslim, aqil dan baligh. Sementara di ayat (2) menyebutkan, wali nikah terdiri dari, wali nasab dan wali hakim. Kemudian di dalam pasal 21, 22 dan 23 diterangkan tentang hirarki wali dan peran wali hakim dalam pernikahan. $^{13}$

\section{BIOGRAFI SINGKAT MUSDAH MULIA}

Nama lengkap Prof. Dr. Siti Musdah Mulia, M. A, APU, lahir di Bone, Sulawesi Selatan, 3 Maret 1958 (sekarang berumur 60 tahun). Anak pertama (sulung) dari pasangan Mastamin Abdul Fattah dan Buaidah Achmad. Ia menikah pada tahum 1984, suaminya Ahmad Thib Raya adalah guru besar Pascasarjana UIN Syarif Hidayatullah, Jakarta. $^{14}$ Dosen Pascasarjana UIN Syarif Hidayatullah itu dinilai sebagai sosok

12 Wahbah Az-Zuhaili, Fiqih Islam Jilid 9, terjemahan dari Al-Figh Al-Islamiy Wa Adillatubu, oleh Abdul Hayyie al-Kattani, dkk, (Jakarta: Gema Insani, 2011), 194

13 Direktorat Pembinaan Badan Peradilan Agama Islam (DPBPAI), Kompilasi Hukum Islam di Indonesia, (Jakarta: DPBPAI, 1997), 24-25

14 Eka Suriansyah, "Merombak Struktur, Membentuk Kultur; Studi Pemikiran Siti Musdah Mulia”, Jurnal Studi Agama dan Masyarakat, Vol. 13, No. 2, Desember 2017, 296 muslimah yang mau dan berani bersuara. Sosok perempuan ini sudah sangat dikenal banyak kalangan, terutama kalangan pemerhati dan aktivis isu perempuan (feminist) di Tanah Air. Kiprahnya dalam menyuarakan, membela dan mengembalikan hak-hak perempuan dimata agama telah berlangsung dalam jangka waktu cukup lama. ${ }^{15}$

Tidak aneh jika Musdah mempunyai ketertarikan teramat sangat kepada wacana agama, sebab selama puluhan tahun Musdah berkecimpung dan menekuni teks-teks keagamaan Islam, baik ketika masih di pesantren maupun ketika menempuh pendidikan di pergurun tinggi. Selain menekuni pendidikan formal, Musdah juga mengikuti pendidikan non-formal di banyak Negara, seperti Kursus Singkat mengenai Islam dan Civil Society di Universitas Melbourne, Australia. (1998); Kursus Singkat Pendidikam HAM di Universitas Chulalongkorn, Thailand (2000); Kursus Singkat Manajemen Pendidikan dan Kepemimpinan Perempuan di Bangladesh Institute of Administration and Management (BIAM), Dhaka, Bangladesh (2002); dan lainnya. Selain itu Musdah memiliki banyak pengalaman seperti menjadi dosen luar biasa dan peneliti di beberapa universitas di Indonesia, serta pernah menjadi direktur di salah satu perguruan tinggi swasta. ${ }^{16}$

Selain itu, tidak sedikit amanah yang dijalani dalam Birokrasi Organisai Pemerintahan, serta sebagai peneliti dan dosen juga aktif menjadi trainer di berbagai pelatihan, khususnya dalam isu demokrasi, HAM, kesetaraan gender, pluralisme, penegakan hak perempuan dan Civil Society. Banyak lagi pengalaman dan aktivitas yang diikuti oleh Musdah sampai sekarang, seperti menghadiri dan juga aktif menjadi trainer (instruktur) di

15 Budi Hadrianto, 50 Tokoh Islam Liberal Indonesia; Pengusung Ide Sekularisme, Pluralisme dan Liberalisme Agama, (Jakarta: Hujjah Press, 2007), 235

${ }^{16}$ Eka Suriansyah, Merombak ..., 297 
berbagai pelatihan, pertemuan, seminar dan konferensi internasional di sejumlah mancanegara seperti Amerika, Asia, Afrika dan lain-lain dalam berbagai program advokasi, pelatihan, penelitian dan konsultasi untuk pemberdayaan masyarakat, khususnya yang bertemakan demokrasi, pluralisme, HAM, kesetaraan gender dan keadilan demi membangun masyarakat yang menjunjung tinggi nilai-nilai spiritual dan nilai-nilai kemanusiaan tentang perempuan. ${ }^{17}$

Pemikiran Siti Musdah Mulia sangat kentara dipengaruhi oleh beberapa tokoh. Ia mengaku dalam hal keagamaan banyak dipengaruhi dan menaruh hormat pada pemikiran Harun Nasution dan Nurcholish Madjid. Dalam hal gender ia mengaku banyak dipengaruhi oleh Feminis Muslim seperti Fatimah Mernissi, Nawal Sadawi, Abdullahi an-Naim, dan Qasim Amin. ${ }^{18}$ Pemikiran Musdah Mulia juga tidak bisa dikatakan terlepas dari pemikiran feminis yang lain, seperti Amina Wadud, tokoh wanita yang gigih memperjuangkan kesetaraan gender dan membebaskan diri dan kaumnya. ${ }^{19}$

Elaborasi dari pemikiran para tokoh mempengaruhinya, hingga pemikiran Musdah Mulia berkutat pada pusaran isu-isu demokrasi, hak asasi manusia, gender dan pluralisme. Ideidenya tersebut tersebar di berbagai karyakaryanya, seperti Islam dan Inspirasi Kesetaraan Gender, Muslimah Reformasi; Perempuan Pembaharu Bangsa dan magnum opus kontroversialnya Counter Legal Drafting (CLD) KHI tahun 2004. Dalam pengkajian CLD-KHI Musdah Mulia masuk sebagai ketua tim perumusnya merupakan pintu masuk dalam memahami ideide pembaharuannya tentang hukum Islam di Indonesia. ${ }^{20}$

17 Nurul Ma"erifah, "Perkawinan di Indonesia; Aktualisasi Pemikiran Musdah Mulia”, Mabkamah, Vol. 9, No. 1, Januari 2015, 68

${ }^{18}$ Eka Suriansyah, Merombak ..., 300

${ }^{19}$ Nurul Ma ${ }^{e e}$ rifah, Perkawinan ..., 64

${ }^{20}$ Eka Suriansyah, Merombak ..., 300
Meskipun ide pembaruannya dalam CLD-KHI dilarang untuk disebarluaskan, Musdah tidak berhenti begitu saja. Tidak berhasil dengan CLD-KHI, ia terus menyuarakan isu-isu gender bersama kawankawannya, baik di ICRP maupun Jaringan Islam Liberl (JIL) dibantu The Asia Foundation yakni lembaga donasi dari Amerika yang sering mendukung gagasan liberalisme. Ia bahkan muncul bersama para penulis buku Fikih Lintas Agama, yang oleh sebagian kaum Muslim dianggap banyak membuang makna teks dan menggunakan aspek konteks yang amburadul. ${ }^{21}$

Berdasarkan hal tersebut di atas, perbincangan mengenai Musdah Mulia selalu diidentikkan dengan sosok kontroversial. Penghalal Homo Seksual, Tokoh Nikah Beda Agama, Sesat dan banyak lagi istilah-istilah yang disematkan padanya oleh kelompok yang menolak ide- idenya. Sebaliknya adalah istilah Sang Pembaharu, Pejuang Perempuan, Pembela Hak Asasi Manusia adalah istilah apresiatif dari kelompok yang memahami ide brilliantnya. Istilah tersebut kemudian memposisikannya sebagai seorang yang multi face. ${ }^{22}$ Idenya dalam pembaruan hukum keluarga Islam disebut sebagai salah satu upaya untuk memecahkan problematika yang masih menjamur di tengahtengah masyarakat Indonesia.

\section{MUSDAH MULIA DAN PEMBARUAN HUKUM KELUARGA ISLAM DI INDONESIA}

Hukum adalah aturan-aturan normatif yang mengatur pola perilaku manusia. Hukum tidak tumbuh di ruang vakum, melainkan tumbuh dari kesadaran masyarakat yang membutuhkan adanya suatu aturan bersama. Sebagai produk sosial dan kultural bahwa juga produk politik yang bernuansa ideologi, 
hukum idealnya selalu bersifat kontekstual. ${ }^{23}$ Sebuah fakta yang tidak bisa ditolak bahwa hukum Islam pada umumnya menganut prinsip dinamis (at- taghayyur). Hukum Islam berubah sesuai dengan perubahan ruang, waktu dan person di dalamnya. Sementara Islam itu sendiri kita kenal sebagai agama universal yang mampu menjawab problematika yang terjadi. Islam juga mengenal perpaduan antara apa yang disebut konstan-nonadaptable (tsabat) dan elastis-adaptable (murunah). ${ }^{24}$

Fikih merupakan ajaran non-dasar yang paling banyak diimplementasikan dalam masyarakat Islam. Sebagai rekayasa cerdas pemikiran manusia tidak ada jaminan bahwa pandangan fikih tidak mengandung kesalahan atau kekeliruan dari dalam dirinya. Suatu hasil ijtihad biasanya dipengaruhi oleh faktor-faktor sosio kultural dan sosio historis masyarakat pada masa kehidupan para ulama pelaku ijtihad tersebut. Oleh karena itu, suatu hasil ijtihad tidak berlaku abadi, boleh jadi cocok untuk kurun waktu tertentu, namun belum cocok pada kurun waktu yang lain, begitupun terhadap masyarakatnya. ${ }^{25}$

Upaya-upaya pembaruan dalam hukum keluarga Islam sangat mungkin dilakukan sepanjang tetap mengacu kepada nilai-nilai moral Alquran yang dijabarkan ke dalam enam prinsip pokok sebagai berikut. Pertama, adanya dinamika zaman yang terus berkembang dan melahirkan berbagai bentuk perubahan sosial; Kedua, pembaruan hukum tidak dilakukan terhadap hal-hal yang bukan menyangkut prinsip-prinsip dasar agama, tetapi hanya berkisar pada masalah-masalah fikih; Ketiga, pembaruan didasarkan kepada

${ }^{23}$ Musdah Mulia, "Menuju Hukum Perkawinan yang Adil; Memberdayakan Perempuan Indonesia", dalam buku Sulistyowati Irianto, Perempuan dan Hukum; Menuju Hukum yang Berperspektif Kesetaraan dan Keadilan, (Jakarta: Yayasan Obor Indonesia, 2006), 133

${ }^{24}$ Syaiful Bahri, "Kontribusi Pemikiran Qasim Amin dalam Pembaruan Hukum Keluarga Islam”, AlAbwal, Vol. 6, no. 1, 2013, 18

${ }^{25}$ Musdah Mulia, Menuju ..., 145 prinsip "menjaga yang lama yang masih relevan dan mengambil yang baru yang lebih baik"; Keempat, pembaruan tersebut harus diikuti dengan sikap kritis terhadap khazanah ulama klasik dengan tanpa menghilangkan rasa hormat terhadap mereka; Kelima, pembaruan berarti pemahaman dan pengkajian kembali terhadap seluruh tradisi islam, termasuk penafsiran Alquran dan hadits, dengan memahaminya secara moral, intelektual dan kontekstual dengan tidak terpaku kepada legalformalnya hukum yang cenderung parsial dan lokal; Keenam, pembaruan tetap berpegang kepada maqashid al-syari" ab dan demi tercapainya kemaslahatan umat. ${ }^{26}$

Salah satu bentuk pembaruan hukum keluarga dalam konteks nasional Indonesia adalah dengan hadirnya Kompilasi Hukum Islam (KHI). KHI bagi Musdah mengandung dua hal, di satu sisi memang memudahkan kerja para hakim agama dan pihak lainnya yang mencari rujukan hukum, tetapi di sisi lain jelas memangkas kreativitas dan upaya-upaya ijtihad dalam bidang hukum keluarga. Sementara itu persoalan-persoalan baru terus bermunculan mengikuti dinamika masyarakat dan perkembangan sains dan teknologi. Di sisi lain rujukan hukum tidak berubah, hal ini pada gilirannya menimbulkan kesulitan baru bagi para hakim agama di lapangan. ${ }^{27}$

Lebih dari itu, dari sisi kesetaraan dan keadilan gender, sejumlah pasal KHI dinilai memarjinalkan perempuan. KHI mengukuhkan pandangan dominan dalam fikih yang menempatkan perempuan sebagai "urutan kedua" setelah laki-laki, seperti dalam soal wali, saksi, nusyur, poligami serta dalam hak dan kewajiban suami isteri. Padahal menurut Musdah pihak yang menikah dan

26 Siti Musdah Mulia, Islam dan Inspirasi Kesetaraan Gender, (Yogyakarta: Kibar Press, 2007), 156157

${ }^{27}$ Ibid., 157 
membentuk keluarga itu bukan hanya laki-laki, tapi juga perempuan. ${ }^{28}$

Dari perspektif budaya, KHI juga dipandang kurang merepresentasikan kebutuhan dan keperluan umat Islam di Indonesia karena tidak digali secara seksama dari kearifan lokal masyarakat di berbagai daerah, melainan diangkut begitu saja dari fikih klasik yang bernuansa arab. Ketidakrelevanan fikih-fikih klasik itu, oleh karena ia disusun dalam era, kultur dan imajinasi sosial yang berbeda. ${ }^{29}$

Meski demikian, Musdah mengakui sejumlah terobosan baru yang dilakukan KHI dalam pembaruan hukum keluarga Islam, sebab pembaruan tersebut cukup signifikan dibandingkan dengan pandangan kitab fikih, seperti pada defenisi perkawinan, pencatatan perkawinan, batasan usia perkawinan, taklik talak dan lainnya. Artinya, dibanding kitab fikih tradisional KHI lebih kuat dalam melindungi hak dan status perempuan, serta cukup progres merespon tuntutan dinamika masyarakat pada masanya. Pembaruan itu ternyata dapat diterima masyarakat Islam Indonesia. ${ }^{30} \mathrm{Hal}$ inilah yang menurutnya telah mengindikasikan bahwa pembaruan hukum berikutnya adalah suatu keniscayaan.

Salah satu upaya pembaruan yang dimaksudkan oleh Musdah Mulia adalah merumuskan hukum baru yang lebih sesuai dengan konteks perkembangan zaman hari ini, yaitu mengajukan draft baru (Counter Legal Draft Kompilasi Hukum Islam - CLD-KHI) untuk memperbarui beberapa pasal KHI yang dianggap tidak lagi mapan dengan kondisi masyarakat hari ini. CLD-KHI sebagai klarifikasi terhadap isi KHI yang padanya masih terdapat kesalahan tafsir, utamanya tertuju pada sisi-sisi perkawinan yang telah dianggap mapan selama ini.

\footnotetext{
${ }^{28}$ Musdah Mulia, Meпијu ..., 142

${ }^{29}$ Siti Musdah Mulia, Islam dan Inspirasi ..., 159

${ }^{30}$ Musdah Mulia, Мепијu ..., 143
}

Tidak sedikit penolakan yang muncul terhadap perumusan aturan baru dalam CLDKHI, baik dari pemerintah yang diwakili oleh Menteri Agama waktu itu, juga dari salah seorang Guru Besar Hukum Islam di Fakultas Syarielah dan Hukum, UIN Syarif Hidayatullah, yaitu Huzaemah Yahido Tanggo yang menilai bahwa materi-materi CLD-KHI bertentangan dengan Alquran dan hadits serta sumber-sumber hukum Islam lainnya yang $m u$ "tabarah, termasuk persoalan ketiadaan wali nikah. ${ }^{31}$ Selain Huzaemah, Rifyal Kab"eah selaku Hakim Agung Mahkamah Agung RI juga menolak keberadaan draft yang diajukan oleh Musdah bersama tim, ${ }^{32}$ bahwa pembaruan yang diajukan menurut Rifyal bukanlah pembaruan dalam konteks pemurnian dan perbaikan terhadap keburukan, akan tetapi dalam pengertian penyimpangan dan perubahan dari hukum Islam yang asli. ${ }^{33}$

CLD-KHI, menurut Musdah Mulia, harus dilihat sebagai ijtihad untuk mempromosikan ajaran Islam yang menekankan cinta dan kehormatan untuk manusia dan berusaha untuk menghilangkan semua bentuk deskriminasi, eksploitasi, dan kekerasan terutama dalam kehidupan rumah tangga. Selain itu, sebagai sebuah upaya untuk mencari solusi untuk sejumlah permasalaha sosial kontemporer yang dihadapi masyarakat Indonesia. ${ }^{34}$

Musdah Mulia berpendapat ada empat alasan pembaharuan hukum Islam di

31 Asni, Pembaruan Hukum Islam di Indonesia; Telaah Epistimologis Kedudukan Perempuan dalam Hukum Keluarga, (Jakarta: Kementerian Agama RI, 2012), 251

32 Pendanaan proyek CLD-KHI dari pihak asing, The Asia Foundation yang mengatasnamakan Departemen Agama RI

33 Rifyal Kab"ah, "Kompilasi Hukum Islam Tandingan”, Suara Uldilag, Vol. 11, No. 6. April 2005, 35

34 Siti Musdah Mulia, "Muslim Family Reform In Indonesia: A Progressive Interpretation of The Quran”, al-Mawarid; Journal of Islamic, Vol. XV, No. 1, Agustus 2015, 16 
Indonesia harus dimulai dari KHI yaitu Pertama, KHI dipandang sebagai jantung syariat atau inti ajaran Islam sehingga menjadi rujukan nilai di masyarakat. Kedua, KHI merupakan panduan hukum hakim agama di Pengadilan Agama dalam memutuskan perkara-perkara keluarga, khususnya di bidang perkawinan. Ketiga, upaya mengeliminasi semua bentuk diskriminasi terhadap perempuan harus dimulai dari keluarga. Sebab, keluarga yang katanya merupakan wilayah yang paling aman itu justru paling banyak merekam kasus-kasus kekerasan dalam rumah tangga (domestic violence). Keempat, sejumlah pasal dalam KHI berseberangan dengan undang-undang baru, seperti Amandemen UUD 1945, UU No. 7 tentang Rativikasi CEDAW (The Convention on The Elimination of All Form Discrimination Agianst Women) adalah instrumen standar internasional menetapkan persamaan hak antara laki-laki dan perempuan yang diadopsi oleh PBB pada tahun 1979 dan mulai berlaku pada tanggal 3 Desember 1981 dan UU No. 39 Tahun 1999 tentang Hak Asasi Manusia. ${ }^{35}$

\section{PANDANGAN MUSDAH TENTANG WALI NIKAH}

Alquran menyebut perkawinan sebagai kontrak atau perjanjian yang serius (mitsaqan ghaliza), terlihat dari adanya unsur ijab (tawaran) dan qabul (penerimaan). Itulah sebabnya mengapa bahasan tentang perkawinan dalam kitab-kitab fikih tidak dimasukkan ke dalam bahasan ibadah, melainkan muamalat (transaksi sosial). Sebagai sebuah kontrak sosial seharusnya yang melakukan ijab-qabul adalah calon suami dan calon isteri sehingga keduanya secara psikologis merasa terlibat dalam perjanjian tersebut dan menimbulkan tanggung jawab

\footnotetext{
35 Siti Musdah Mulia, Islam dan Inspirasi ..., 166
}

bersama dalam perkawinan. ${ }^{36}$ Sejalan dengan defenisi perkawinan yang dipaparkan oleh Musdah bahwa perkawinan merupakan sebuah akad atau kontrak yang mengikat dua pihak yang setara yaitu laki-laki dan perempuan yang masing-masing telah memenuhi persyaratan hukum atas atas dasar kerelaan dan kesukaan. ${ }^{37}$

Namun praktiknya, kontrak tersebut dilakukan oleh dua orang laki-laki, yaitu calon suami dan ayah atau wali dari calon isteri. Jadi kontrak antara dua laki-laki, bukan antara lakilaki dan perempuan yang dinilai setara, artinya kedua calon laki-laki dan perempuan yang harusnya bersepakat secara sukarela. Menurut Musdah hal ini terjadi karena munculnya anggapan bahwa perempuan bukanlah manusia yang merdeka, dewasa dan mandiri seperti laki-laki. Karena perempuan tidak dapat mengambil keputusan sendiri, maka persetujuan perkawinan harus datang dari para wali. Anggapan itu tidak hanya ada dalam benak laki-laki, melainkan diyakini pula oleh perempuan itu sendiri. Ironisnya lagi, menurut Musdah hal tersebut mendapat pembenaran dari pemahaman agama, seperti Islam yang sebagian besar pemeluknya menganggap perempuan sebagai makhluk yang lemah akal dan lemah agamanya. ${ }^{38}$

Pembahasan tentang wali nikah dijelaskan dalam pasal 19, 20, 21, 22 dan 23. Pada pasal 19 KHI disebutkan: "Wali nikah dalam perkawinan merupakan rukun yang harus dipenubi bagi calon mempelai wanita yang bertindak untuk menikabkannya." Sementara CLD-KHI merumuskan: "Wali nikah hanya diperlukan bagi perkawinan wanita di bawah usia 21 tabun." CLDKHI membatasi keberadaan wali hanya bagi perempuan yang belum dewasa dan belum 21 tahun. Usia 21 tahun dinilai sebagai batas

36 Siti Musdah Mulia, "Islam dan Hak Asasi Manusia; Konsep dan Implementasi, (Yogyakarta: Naufan Pustaka, 2010), 123

${ }^{37}$ Siti Musdah Mulia, Islam dan Inspirasi ..., 134

38 Siti Musdah Mulia, Islam dan Hak ..., 123-

124. Lihat juga - Siti Musdah Mulia, Kemuliaan ..., 67 
kematangan dan kedewasaan seseorang sekaligus berhak mengambil keputusan penuh sebagai subyek hukum. ${ }^{39}$ Artinya, CLD-KHI memerlukan wali hanya jika pengantin wanita tidak memiliki kapasitas hukum untuk menikah karena tidak cukup umur, kurang akal atau belum dewasa.

Fikih mensyaratkan wali dalam perkawinan hanya diperlukan bagi perempuan. Mereka yang berhak sebagai wali hanyalah para laki-laki, yaitu: ayah, ayahnya ayah (kakek), saudara laki-laki kandung, saudara laki-laki seayah saja, anak saudara laki-laki (keponakan laki-laki dari saudara laki-laki), saudara lakilaki ayah (paman laki-laki dari pihak ayah) dan seterusnya. Dalam kaitannya dengan wali tidak ada celah sama sekali bagi perempuan. Artinya, laki-laki dan perempuan, meskipun sama-sama makhluk Tuhan dan sama-sama manusia, namun berbeda derajatnya dalam perwalian. Keduanya sangat berbeda dalam hal penilaian dan penghargaan. Laki-laki superordinat, sedang perempuan subordinat. ${ }^{40}$ Hal itulah yang membuat Musdah mengeluarkan gagasan baru yang dianggap lebih memberikan solusi terhadap persoalan yang ada.

Musdah mengakui bahwa gagasan ini bukanlah hal yang baru, karena yang demikian itu sudah dilakukan oleh Imam Abu Hanifah pada abad ke-9 masehi. Pembahasan ini telah diketahui bahwa ulama berbeda pendapat tentang kedudukan wali sebagai syarat sah nikah atau tidak menjadi syarat sah. Imam Malik dan Imam Syafie $i$ berpendapat wali merupakan syarat sah nikah. Nikah tanda wali berarti batal (tidak sah). Sebaliknya menurut Imam Abu Hanifah, Zafar, al- Sya "ebi dan alZuhri jika perempuan mengawinkan dirinya tanpa persetujuan walinya, sedang suaminya masih dalam kepantasan (layak dan sekufu), maka perkawinannya tetap sah. Berbeda

\footnotetext{
${ }^{39}$ Musdah Mulia, "Meniju ..., 154

40 Ibid.
}

dengan Imam Dawud al-Zahiry, dia membedakan status gadis dan janda. Perempuan yang masih gadis wajib disertai wali, sedang yang sudah janda tidak disyaratkan wali. ${ }^{41}$

CLD-KHI mengkompromikan kedua pandangan berbeda dengan menawarkan solusi bahwa perempuan berusia di bawah 21 tahun masih memerlukan persetujuan wali dalam perkawinan demi kemaslahatan, sementara jika sudah berusia 21 tahun perempuan dipandang dewasa dan mandiri, mampu mengambil keputusan hukum sehingga tidak memerlukan persetujuan wali dalam perkawinan. Akan tetapi, tiadanya persetujuan wali tidak dimaksudkan bahwa kehadiran dan restu orang tua dalam perkawinan tidak diperlukan lagi. ${ }^{42}$

Menurut Mudah menikah dan berkeluarga merupakan hal yang paling asasi dalam diri manusia, baik itu laki-laki maupun perempuan. Tidak seorangpun bisa dihalangi atau dipaksa dalam perkawinan. Menikah adalah sebuah hak yag didasarkan pada pilihan bebas, bukan kewajiban. Penegasan ini diperlukan karena di kalangan masyarakat luas masih banyak dijumpai praktik pemaksaan dalam perkawinan, terutama di lingkungan pedesaan yang dijadikan sebagai salah satu modus operandi dari kegiatan perdagangan perempuan dan anak. Tidak sedikit orang tua yang menjual anak gadis mereka demi uang atau bahkan demi alasan agama, misalnya yang terjadi di daerah Gunung Putri, Jawa Barat, perkawinan paksa yang dilakukan untuk mendapatkan berkah dari keturunan Arab. Maka mutlak adanya persamaan dan keseimbangan hak dan kewajiban bagi laki-laki dan perempuan dalam pernikahan mereka, untuk menghindari eksploitasi terhadap perempuan. ${ }^{43}$ Ia juga beranggapan dengan

${ }^{41}$ Ibid., 155
${ }^{42}$ Ibid., 156
43 Siti Musdah Mulia, Kemuliaan Perempuan dalam Islam, (Jakarta: PT. Elex Media Komputindo, 2014), 64 
tidak menjadikan keberadaan wali sebagai rukun nikah maka dapat mengeleminir berbagai tindak kekerasan nikah paksa dengan berdalihkan wali mujbir. ${ }^{44}$ Jika keberadaan wali nikah tetap ada, maka akan ada hak perempuan akan hilang, yaitu hak dan kebebasan yang sama bagi laki-laki untuk memilih pasangan hidup dengan persetujuan penuh.

Menentukan pilihan terhadap siapa yang menjadi pasangan dalam pernikahan adalah hak kebebasan memilih bagi laki-laki dan perempuan. Pada masa sebelum Islam (tradisi Arab), perempuan tidak punya hak memilih bahkan diposisikan sebagai barang yang bisa dimiliki oleh ayah dan wali, dimana mereka bebas menentukan siapa yang akan menjadi pendamping atas perempuan tersebut. Ketika Islam datang, tradisi tersebut dirubah dengan adanya riwayat yang menjelaskan tentang seorang janda lebih berhak atas dirinya, sedangkan gadis dimintai persetujuannya. Moral Islam menawarkan tempat yang sangat signifikan untuk perempuan untuk memperjuangkan haknya sebagai manusia yang setara dengan laki-laki. Hal ini hendaknya juga memberi wawasan dan pengertian kepada orang tua atau wali. ${ }^{45}$

Uraian di atas menjelaskan bahwa gagasan yang ditawarkan oleh Musdah tentang ketiadaan wali nikah dalam rukun pernikahan, secara umum bertolak dari anggapan bahwa hukum tentang wali dalam pernikahan yang telah diatur di dalam KHI sudah tidak sesuai dan tidak mapan lagi untuk diterapkan pada saat sekarang. Oleh karena itu, sudah selayaknya mengajukan revisi terhadap pasal KHI tersebut.

${ }^{44}$ Eka Suriansyah, Merombak ..., 306

45 Ahmad Masfuful Fuad, "Cedaw and The Rights of Kindship in Islamic Family Law", al-Mawarid, Journal of Islamic Law, Vol. XV, No. 1, Agustus 2015, 184.

\section{TIPOLOGI PEMIKIRAN MUSDAH} MULIA TENTANG WALI NIKAH

Gagasan Musdah muncul tentu memiliki latar belakang yang kuat sehingga berani mengeluarkan ide untuk meniadakan wali dalam rukun nikah dan hal tersebut perlu diketahui terlebih dahulu. Berdasarkan hasil wawancara penulis dengan Musdah Mulia, ada tiga hal penting yang melatarbelakangi munculnya ide yang dinilai ektrim tersebut: Pertama, adanya wali nikah dinilai melanggar Hak Asasi Manusia (HAM). Dengan adanya kewajiban wali bagi perempuan, pasal KHI dinilai telah mengekang hak perempuan atas dirinya dan menghilangkan hak kuasa yang merupakan hak dasar setiap manusia. Alasan ini tercermin dalam pemikiran Musdah tentang ajaran tauhid sebagai inti ajaran Islam yang menghapuskan semua sekat-sekat deskriminasi dan subordinasi. Artinya, manusia baik laki-laki atau perempuan mengemban tugas ketauhidan yang sama. ${ }^{46}$ Kasus wali yang mewajibkan wali bagi perempuan sementara laki-laki berkuasa atas dirinya sendiri tanpa harus ada wali, bagi Musdah jelas melanggar HAM.

Kedua, adanya wali dapat menimbulkan ketidakadilan gender. Dari pengamatan penulis, alasan ini bukan berarti menuntut perempuan menjadi wali, akan tetapi sepertinya Musdah ingin menegaskan bahwa jelaslah KHI (pasal 20) telah mendudukkan posisi perempuan sangat berbeda dengan lakilaki. Perempuan tidak hanya dituntut menyertai wali akan tetapi juga tidak diberi peluang sama sekali berperan sama dengan laki-laki. Adanya kenyataan demikian menurut Musdah menjadikan laki-laki dan perempuan dipandang berbeda derajatnya dalam perwalian dan sangat berbeda dalam penilaian, laki-laki superordinat sedang perempuan subordinat. Juga mengingat bahwa KHI ataupun fikih klasik selama ini didominasi oleh struktur patriarki yang sifatnya maskulin gender.

46 Siti Musdah Mulia, Islam dan Inspirasi ..., 10 
Ketiga, adanya wali menghalangi terwujudnya kemaslahatan sosial, seperti mewajibkan wali bagi perempuan akan mengekang hak perempuan sementara laki-laki dapat memilih sesukanya. Selain itu kemungkinan adanya trafficking sehingga perempuan dijual dengan berbagai alasan misalnya dengan dalih wali mujbir. Asumsi penulis terhadap poin ketiga ini adalah untuk mencapai kemaslahatan yang diinginkan, maka pasal KHI tentang wali harus ditinjau kembali (reinterpretasi) dengan mempertimbangkan aspek HAM dan kesetaraan gender. Secara tidak langsung hal ini juga menerangkan bahwa peran wali sebagai pelindung bagi perempuan sudah tidak mapan lagi untuk saat ini.

Berdasarkan ketiga pokok masalah tersebut, Musdah menyimpulkan bahwa wali nikah bukan bagian rukun nikah dan bukan pula menjadi tolak ukur dalam menentukan sah atau tidaknya sebuah pernikahan. Artinya seorang perempuan boleh menikahkan dirinya sendiri tanpa wali. Selain itu, Musdah juga beranggapan bahwa kedudukan wali yang telah dirumuskan oleh para ulama berbeda-beda, sehingga ada peluang untuk meniadakan wali nikah. Sekaligus ingin memberitahu bahwa sebuah ketentuan yang belum ada kepastian dari nash, padanya masih ada peluang berijtihad, termasuk tentang perihal wali. Diakui oleh Musdah bahwa pemikiran tersebut, dihasilkan dari penelitiannya terhadap alquran dan didominasi oleh pemahamannya tentang HAM dan kesetaraan gender.

Jika diperhatikan, gagasan Musdah memiliki persamaan dengan pendapat salah seorang ulama klasik yang masyhur yaitu Imam Abu Hanifah. Imam Abu Hanifah dan ulama Hanafiyah tidak mewajibkan wali tanpa membedakan gadis atau janda, kewajiban wali hanya ada pada anak kecil; kemudian juga tidak mensyarakatkan laki-laki sebagai wali sebab perempuan dewasa punya atas dirinya; serta tidak ada hak ijbar bagi perempuan dewasa. Sementara pendapat Musdah juga tidak mewajibkan wali, kecuali bagi usia sampai 21 tahun sebagai batas kematangan dan kedewasaan seseorang; tidak mensyaratkan wali itu laki-laki bahkan lebih kepada meniadakan wali; juga tidak ada wali ijbar. Adapun perbedaannya, Musdah dalam konteks kekinian berani menuangkan pemikiran tersebut ke dalam bentuk CLDKHI sebagai pengganti KHI dengan membawaka isu HAM dan kesetaraan gender. Inilah yang menjadi perbedaan menonjol antara keduanya, mengingat perbedaan zaman dan tempat yang melingkupi masing-masing tokoh.

Bahasan di atas menjadi pijakan bagi penulis dalam inti penelitian ini, yaitu tipologi pemikiran Musdah Mulia tentang wali nikah dalam rukun pernikahan. Tipologi dalam hal ini adalah cara pandang Musdah dalam melihat persoalan wali nikah, karena sejatinya setiap intelektual muslim punya cara pandang tersendiri dalam memahami hukum Islam. Munculnya tipologi pemikiran hukum yang beragam, menurut Azyumardi Azra, bertolak dari asumsi atau pandangan bahwa Islam sebagai realitas dan lingkungan sosial tidak sesuai dengan Islam ideal, sesuai dengan cara pandang, pendekatan, latar belakang sosio kultural dan kegamaan individu dan kelompok pembaru tersebut. ${ }^{47}$

Jika ditelusuri kembali ke masa awal sejarah perkembangan hukum Islam. Pemikiran para ulama atau mujtahid di zaman itu selalu dipengaruhi oleh konteks di mana ulama itu berada dan dengan siapa ia sering melakukan komunikasi sosial, seperti Imam Abu Hanifah yang lebih dikenal sebagai $a b l$ al-ra'y karena lebih banyak menggunakan porsi akal dalam ijtihadnya. Sementara Imam Malik lebih banyak menggunakan hadits dan

47 Imam Syaukani, Rekontruksi Epistimologi Hukum Islam Indonesia dan Relevansinya Bagi Pembangunan Hukum Nasional. (Jakarta: PT. Raja Grafindo, 2006), 20 
tradisi masyarakat Madinah, dan lainnya. Bertolak dari uraian tersebut, melihat apa yang berlaku bagi para mujtahid sebelumnya, demikian halnya yang penulis cermati terhadap pemikiran Musdah sebagai sosok fenomenal yang dikenal dengan gagasan-gagasannya yang ekstrim, tentunya dalam konteks zaman yang berbeda.

Selanjutnya, pemikiran Musdah tentang ketiadaan wali dalam pernikahan apabila dihubungkan dengan pemikiran Islam tradisional, penulis tidak menemukan argumen yang mumpuni. Musdah dalam gagasannya sangat menjunjung aspek kontekstual dan kritis terhadap pendapat ulama, berbeda halnya dengan pemikir tradisional yang cenderung tekstual serta mengikat diri pada pendapat ulama generasi awal.

Sementara itu, kaitannya dengan Islam moderat dalam penetapan hukumnya mengedepankan kontekstualisasi tanpa mengabaikan nash sebagai sentral analisis, yaitu yakin bahwa hukum Islam bersifat dinamis, sebab setiap produk hukum tidak bisa ditetapkan tanpa melihat pengaruh yang melingkupinya, baik sosio-kultural maupun sosio-politis. ${ }^{48}$ Bagi Musdah suatu hasil ijtihad dapat diterima, tapi hal itu tidak menghalangi untuk berpikir kritis atau mencegah kita menerima hasil ijtihad lain yang berbeda namun justru sangat sesuai dengan kemashlatan kita. Di sini Musdah tidak ingin mengenyampingkan peran akal dalam mengkritik hasil ijtihad, karena tidak tertutup adanya kekeliruan padanya. Oleh karena itu secara umum, terlihat kesesuaian pemikiran Musdah dengan Islam moderat, namun dalam hal ini tampak bahwa Musdah cenderung didominasi oleh akal, mengingat tidak ada dalil yang dikemukakan oleh Musdah dalam gagasannya dan itu bukanlah cerminan dari karakter Islam moderat.

${ }^{48}$ Musdah Mulia, Menuju ..., 133
Adapun pada Islam liberal terdapat kecenderungan pemikiran Musdah di dalamnya yaitu menolak segala bentuk penindasan terhadap perempuan, termasuk hak dan kebebasan menikah tanpa wali. Adapun dari tiga isu yang disuarakan oleh kelompok liberal yaitu kesetaraan agama, kesetaraan gender dan HAM, Musdah termasuk yang giat menyuarakan dua isu terakhir dalam kaitannya dengan wali nikah. Aplikasi kesetaraan gender dan HAM tersebut diupayakan melalui sebuah sebuah konsep dalam draft baru. Meskipun tawarannya untuk revisi sempat ditolak, Musdah menyatakan tidak akan berhenti menyuarakan isu tersebut dengan menguatkan upaya- upaya pemberdayaan masyarakat, terutama kaum perempuan melalui penguatan literasi yang berakar pada kemampuan berpikir kritis dan membangun nalar yang sehat, khususnya di tingkat mahasiswa.

Prinsip yang digunakan oleh tokoh Islam liberal dalam menetapkan nilai dalam hukum Islam adalah prinsi keadilan ('adalab), toleransi (tasamub) dan persamaan hak (musawah). Mengistinbatkan nilai dan hukum dari Alquran dan sunah harus memenuhi prinsip-prinsip tersebut, sedangkan nilai detailnya didominasi rasio Musdah dengan prinsip perkawinannya juga mendasarkan kepada dua prinsip yang sama (keadilan dan persamaan hak), disamping tiga prinsip lainnya, yaitu kerelaan (al-taradhi), kemaslahatan (al-maslahat), pluralisme (alta"ddudiyab) dan demokrasi (aldiimuqratbiyyah). ${ }^{49}$ Maka, yang tercermin dalam gagasan Musdah tentang ketiadaan wali nikah, adalah pinsip keadilan (adalab) dan persamaan (al-musawwah).

Jadi ada perbedaan mencolok antara moderat dan liberal, meskipun kedua tipologi ini sama-sama memahami nash secara kontekstual dan menjadikan Islam yang

${ }^{49}$ Ibid., 168 
rahmatan li al-alamin, akan tetapi perbedaan tersebut sangat tampak pada isu yang digandrungi oleh pemikir liberal. Muslim moderat meskipun mencoba memahami nas secara kontekstual, tetapi sentralnya tetap kepada Alquran dan hadits. Tidak sama halnya dengan muslim liberal yang lebih mengemukakan rasio dibanding nash atau bahkan berani keluar dari nash dengan mengedepankan mashlahat, dalam bentuk kesetaraan gender dan HAM.

Selanjutnya, pada Islam progresif jika dikolerasikan dengan pemikiran Musdah terdapat beberapa karakter yang bersesuaian, yaitu: Pertama, mereka mengadopsi pandangan bahwa bidang hukum Islam tradisional memerlukan perubahan dan reformasi substansial dalam rangka menyesuaikan dengan kebutuhan masyarakat muslim saat ini. Kedua, cenderung mendukung perlunya penyegaran ijtihad dan metodologi baru dalam ijtihad untuk menjawab permasalahanpermasalahan kontemporer. ${ }^{50}$

Pada kedua pandangan di atas tercermin dalam pemikiran Musdah tentang wali nikah yang menurut Musdah, aturan perihal wajibnya wali dalam pernikahan untuk saat ini sudah tidak cocok lagi, karena alasanalasan kemanusiaan (HAM, kesetaraan gender dan kemaslahatan sosial umat) yang sudah menjadi kebutuhan masyarakat moderen saat ini, di samping juga tidak ada nash yang mengatur secara tegas. Bagi Musdah syaratsyarat perkawinan tidak ada dalam Alquran, itu hanyalah rumusan dari seorang mujtahid. Maka tidak ada halangan untuk membuat rumusan yang berbeda dari konsep yang sudah ribuan tahun ada dengan ijtihad yang sesuai kebutuhan saat ini. Ini sekaligus merefleksikan karakteristik Islam progresif yang keempat dan kelima, bahwa mereka secara teguh

50 Fathurrasyid, "Islam Progresif Versi Abdullah Saeed: Ikhtiar Menghadapi Problem Keagamaan Kontemporer", al-Ihkam, Vol. 10, No. 2, Desember 2015, 298 berkeyakinan bahwa perubahan sosial, baik pada ranah intelektual, moral, hukum, ekonomi dan teknologi harus direfleksikan dalam hukum Islam. Mereka tidak mengikutkan dirinya pada dogmatisme atau mazhab hukum dan teologi tertentu dengan pendekatan kajiannya. ${ }^{51}$

Sementara pada kerakteristik ketiga, yaitu beberapa diantara mereka juga mengkombinasikan kesarjanaan tradisional dengan pemikiran dan pendidikan Barat modern. ${ }^{52}$ Tidak ada hal yang menunjukkan bahwa Musdah dalam pemikirannya mencoba mengkombinasikan pemikiran tradisional dan barat, mengingat tidak ada landasan dalil yang melatarbelakangi pemikiran tersebut. Keenam, meletakkan titik tekan pemikirannya pada keadilan sosial, keadilan gender, HAM dan relasi yang harmonis antara muslim dan non-muslim. Muslim progresif menggunakan pendekatan humanities kontemporer. ${ }^{53}$ Karakteristik yang terakhir ini sangat jelas terdapat pada pemikiran Musdah, sebagaimana analisis terdahulu yang memaparkan beberapa alasan atau latar belakang pemikiran Musdah tentang ketiadaan wali nikah, yaitu HAM, keadilan gender serta kemaslahatan sosial umat.

Pemikiran muslim progresif juga memiliki tiga agenda besar, yaitu keadilan sosial, kesetaraan gender dan pluralisme. ${ }^{54}$ Dari ketiga agenda besar ini, ada dua agenda yang tertuang dalam pemikiran Musdah tentang wali nikah yaitu keadilan sosial dan kesetaraan

51 Anik Faridah, "Trend Pemikiran Islam Progresif: Telaah atas Pemikiran Abdullah Saeed", alMabsut: Jurnal Studi Islam dan Sosial, Vo. 7, No. 2, 2013, 3

52 Sa'dan Masthuriya "Perkawinan Beda Agama: Perspektif Islam Progresif”, Kontempelasi, Vol.4, No.2, Desember 2016, 325

${ }^{53}$ Yusdani, "Ushul Fikih dalam Hukum Islam Progresif”, Madania, Vol. 19, No. 1, Juni 2015, 63

54 Ali Murti dan Rahmad Nursyahidin, "Muslim Progresif Omid Safi dan Isu-isu Islam Kontemporer", Jurnal Pendidikan Agama Islam, Vol. 12, No. 2, Desember 2015, 232 
gender. Adapun memperjuangkan keadilan yang dimaksud dalam konteks ini dapat dimaknai memandang setara setiap manusia, baik laki-laki ataupun perempuan atau suami maupun isteri. Upaya untuk merubah aturan hukum tentang wali nikah adalah bentuk kepedulian Musdah terhadap keadilan dan kesetaraan gender dalam kehidupan berkeluarga yang telah menjadi keharusan zaman.

Dalam ijtihad-nya Islam progresif menggunakan model context-based ijtibad yaitu sebuah fenomena baru yang mencoba memahami masalah-masalah hukum dalam konteks kesejarahan dan konteks kekiniannya (modern). Pada biasanya, pendapat akhirnya akan mengacu pada kemaslahatan umum sebagai maqasid al-syari'ah..$^{55}$ Pemikir progresif mencoba memecahkan permasalahan hukum yang mendasarkan kepada Alquran kemudian menghubungkannya dengan konteks kekinian sehingga tetap up to date dan bisa diterapkan (kontekstual).

Kehadiran Islam progresif berusaha merumuskan seperangkat hukum Islam demi terciptanya masyarakat berkeadilan yang menjunjung nilai-nilai kemanusiaan, menghargai hak-hak kaum perempuan, meratanya nuansa kerahmatan dan kebijaksanaan, serta terwujudnya kemaslahatan bagi seluruh umat manusia. Terutama bidang hukum keluarga, semua pihak mempunyai kedudukan yang sama terutama relasi gender dalam keluarga setara dan adil tanpa diskriminasi. ${ }^{56}$

Penjelasan di atas menggambarkan tentang perhatian muslim progresif yang sangat besar terhadap nilai-nilai universal Islam (keadilan, kebaikan dan keindahan). Dengan begitu dibanding muslim liberal porsi perhatian muslim progresif lebih besar terhadap gender. Begitu juga Musdah dalam

${ }^{55}$ Fathurrasyid, Islam ..., 300-301

56 Yusdani, "Ushul Fikih ..., 66 pemikirannya tentang wali nikah, memberikan perhatian yang cukup besar terhadap keadilan dan kesetaraan gender, apalagi pendekatan yang digunakan oleh Musdah dalam menuangkan gagasan tersebut adalah murni dari hasil penelitian yang mendalam terhadap Alquran dan Sunnah dengan pendekatan keadilan gender.

Jika diperhatikan dengan seksama antara pemikiran muslim liberal dan muslim progresif terdapat persamaan dalam isu yang dikaji, yaitu keadilan dan kesetaraan gender, HAM, dan pluralisme. Tokoh-tokoh era klasik dianggap lebih mencerminkan kebutuhan masyarakat saat itu ketimbang menjawab persoalan hukum yang memiliki nilai praktis. Namun keduanya tidak sama, sebab muslim progresif menolak kecenderungan untuk berpikir bebas dengan semata-mata mengandalkan akal. Sebagaimana yang dijelaskan bahwa muslim pogresif dalam ijtihadnya tetap memakai nash sebagai landasan berpikir yang kemudian dielaborasikan dengan keilmuan modern (science, social and humanities).

Beranjak dari pemaparan di atas, dapat ditarik point-point pokok tentang kriteria Islam progresif yaitu, muslim progresif dalam ijtihadnya tidak terlalu bertentangan dengan nash (al- Quran dan Sunnah); perhatian pemikir progresif terhadap gender sangat tinggi; dalam menetapkan hukum atau mencari solusi dari suatu persoalan tidak hanya sampai para taraf teori atau gagasan atau pemikiran semata akan tetapi berujung pada praktek yang harus direalisasikan guna menyelesaikan berbagai persoalan khususnya dalam tataran persoalan masyarakat moderen di era kontemporer.

Pemikiran Musdah tentang ketiadaan wali dalam pernikahan jika dikaitkan dengan ciri pemikiran Islam progresif tersebut, maka dapat dilihat kesesuaian antara keduanya yaitu, Musdah dalam menggagas pemikirannya tentang wali tidaklah bertentangan dengan 
nash, karena memang tidak ada nash yang mengatur secara khusus tentang wali nikah. Perhatian Musdah terhadap gender juga menempatkan porsi yang sangat besar pada ijtihadnya dalam menetapkan hukum tentang ketiadaan wali nikah, sebagaimana yang telah penulis paparkan pada penjelasan sebelumnya. Pemikiran Musdah Mulia tidak hanya disalurkan dalam bentuk karya ilmiah (teori) belaka, tetapi Musdah memiliki semangat untuk dapat menuangkannya ke dalam bentuk peraturan hukum (CLD-KHI) agar hukum bisa berlaku menyeluruh dan dengan itu dapat mencapai kemaslahatan sosial umat. Oleh karena itu, pemikiran Musdah tidaklah termasuk kepada pemikir Islam tradisioal ataupun pemikir Islam liberal, tetapi berada di antara dua kategori ektrim tersebut.

Adapun tawaran pemikiran Musdah memang dinilai kontroversional dan mungkin ditolak oleh sebagian besar kalangan masyarakat muslim. Namun kehadiran pemikiran seperti ini bisa diartikan sebagai alternative penyelesaian persoalan hukum Islam sehingga lebih sesuai dengan kehidupan masyarakat kontemporer dengan kondisi kekinian. Adanya penolakan, jika dilihat dari kacamata Islam progresif dianggap sebagai ketidaksiapan kelompok tradisional Islam dalam menerima perspektif yang digunakan sudah menjadi keharusan zaman- seperti gender, HAM, pluralisme dan lainnya. Selain perspektif pemikiran tersebut, secara hakikat memiliki perbedaan nilai dengan keumuman pemahaman ajaran yang telah lama dianut oleh umat Islam.

Berangkat dari data-data yang telah penulis paparkan di atas, pada akhir pembahasan ini, penulis cenderung menyatakan bahwa secara umum pemikiran Musdah memang dikenal liberal. Namun, dalam persoalan ketiadaan wali dalam pernikahan Musdah cenderung mengarah kepada pemikir Islam progresif. Pemikiran Musdah merupakan bagian dari Islam progresif yang menawarkan kemajuan dan perubahan yang mencoba memberi penafsiran baru terhadap ajaran Islam yang bersumber dari Alquran agar lebih sesuai dan selaras dengan tuntutan kemajuan dan perkembangan dunia saat ini. Artinya, Musdah menerima kenyataan masyarakat moderen saat ini, seperti gencarnya disuarakan isu-isu kemanusiaan, yang kemudian mendorong Musdah untuk merangkulnya dalam bentuk penetapan hukum di masyarakat, yaitu melalui draft baru (CLDKHI).

\section{RELEVANSI PEMIKIRAN MUSDAH MULIA DENGAN PEMBARUAN HUKUM KELUARGA INDONESIA}

Sebagaimana yang disebut oleh Yusuf al-Qardhawi bahwa pemikiran atau ijtihad adalah bagian dari pembaruan. Pembaruan dalam pembahasan ini mengarah kepada pemikiran yang muncul sebagai reaksi terhadap tantangan-tantangan internal maupun eksternal yang menyangkut urusan sosial umat. Pembaruan merupakan hasil dari pemikiran, tidak terjadi pembaruan tanpa adanya pemikiran. Upaya Musdah mengangkatkan kembali pendapat Imam Hanafi yang sudah lama (dulunya aktual) kepada zaman yang berbeda, sejatinya dari sisi kajian hukum merupakan suatu pembaruan. Lahirnya pemikiran tersebut merupakan bentuk sebuah reaksi dari pengamatan Musdah terhadap hukum itu sendiri, seperti kasus wali nikah mengandung nilai ketidakadilan gender, di samping kebutuhan zaman juga mendesak hukum agar melakukan suatu perubahan.

Pemikiran Musdah Mulia terhadap pembaruan hukum keluarga bisa dilacak dari gagasannya, dimana wali nikah bukanlah suatu rukun yang harus ada dalam perkawinan masyarakat muslim di Indonesia. Keberanian dan ketegasannya melontarkan ide tersebut tumbuh menjadi persoalan dikalangan masyarakat Indonesia, khususnya di lingkungan akademisi dan praktisi hukum 
keluarga Islam. Tidak dapat dipungkiri bahwa kelima rukun nikah yang tercantum dalam KHI sudah mendarah daging di kehidupan masyarakat Indonesia, jauh sebelum adanya KHI. Masyarakat memahami tanpa terpenuhinya kelima rukun (calon suami, calon isteri, wali nikah, saksi nikah dan ijab kabul) dalam suatu perkawinan maka nikahnya tidaklah sah. Praktis, idenya terkesan ekstrim di tengah-tengah lingkungan yang mayoritas menganut mazhab Syafie $i$. Akhirnya, wacana Musdah banyak mendapat tantangan (kontra) dari para pemikir lain, seperti Said Agil Munawwar, Rifyal Ka'bah dan Huzaemah Tahido Yanggo.

Dapat dipahami bahwa dari sudut kultural masyarakat Indonesia, institusi wali tidak bisa dihapuskan begitu saja, setidaknya untuk saat ini, mengingat kultur ketimuran yang memandang pernikahan sebagai sebuah peristiwa penting (sakral) sehingga harus melibatkan keluarga. Hal ini juga sebagai upaya antisipasi kalau pernikahan tersebut menemui masalah di kemudian hari, pihak keluarga otomatis akan ikut membantu mengupayakan jalan keluar. Lantas, jika ini merupakan gagasan yang baru bagi masyarakat Indonesia, mungkinkah gagasan tersebut masuk ke dalam konteks pembaruan hukum keluarga di Indonesia.

Untuk melihat relevansi pemikiran Musdah tentang wali nikah dengan pembaruan hukum keluarga di Indonesia, tidak cukup hanya melalui defenisi yang ada, perlu diteliti dari beberapa segi lainnya, yaitu segi tujuan pembaruan hukum itu sendiri, segi latar belakang terjadinya pembaruan serta segi metode yang digunakan dalam menerapkan gagasannya tentang ketiadaan wali nikah tersebut.

Sebagaimana yang telah penulis uraikan pada bab terdahulu, bahwa tujuan pembaruan hukum keluarga Islam ada tiga yaitu, Pertama, untuk unifikasi hukum keluarga.
Kedua, demi pengangkatan status perempuan. Ketiga, untuk merespon perkembangan dan tuntutan zaman karena konsep fikih tradisional kurang mampu menjawabnya.

Unifikasi hukum merupakan upaya penyatuan hukum menjadi satu agar berlaku bagi seluruh warga dan menjadi bagian dari sistem hukum nasional. Hukum yang berlaku saat ini (KHI) telah terunifikasi, sehingga hal ini menutup peluang Musdah dan timnya untuk mengajukan perubahan terhadap hukum keluarga Islam. Pembaruan hukum keluarga yang bertujuan untuk mengangkat status perempuan cukup relevan dengan pemikiran Musdah, terlihat dari upaya mengajukan CLD-KHI yang dianggap lebih merespon tuntutan peningkatan status perempuan dalam hal wali nikah yang menempatkan perempuan dalam urutan kedua setelah laki-laki.

Tujuan terakhir dilakukannya pembaruan hukum keluarga Islam adalah untuk merespon perkembangan dan tuntutan zaman karena konsep fikih tradisional kurang mampu menjawabnya. Sejalan dengan itu, Musdah mengungkapkan bahwasanya upaya-upaya pembaruan dalam hukum keluarga Islam sangat mungkin dilakukan, salah satunya dengan adanya dinamika zaman yang terus berkembang dan melahirkan berbagai bentuk perubahan sosial. Perubahan sosial itu melahirkan berbagai persoalan sosial yang menghendaki adanya pembaruan hukum keluarga, seperti merebaknya kasus-kasus deskriminasi perempuan; meluasnya praktik perkawinan anak-anak dibawah umur; dan tingginya angka perkawinan yang tidak dicatatkan dalam bentuk perkawinan sirri atau bawah tangan. ${ }^{57}$

Penulis dalam hal ini juga berpandangan bahwa secara realitas, upayaupaya pembaruan tidak bisa dielakkan karena adanya tuntutan zaman dan keharusan

${ }^{57}$ Musdah Mulia, Menuju ..., 132 
penyesuaian dengan wilayah tempat dimana hukum berada. Hal ini ditujukan agar hukum Islam dalam segala keadaan bisa mewujudkan kemaslahatan. Berdasarkan hal tersebut, jika dilihat dari segi tujuan pembaruan hukum keluarga Islam yaitu dari aspek respon terhadap perkembangan, pembaruan hukum keluarga yang diajukan Musdah Mulia melalui Counter Legal Draft KHI memiliki relevansi yang cukup besar.

Di samping uraian tersebut, penulis melihat ide Musdah tentang ketiadaan wali nikah dalam rukun pernikahan atau bolehnya perempuan menikahkan dirinya sendiri memang dapat menghilangkan deksriminasi dan mengangkat derajat perempuan kepada yang lebih terhormat. Tawaran Musdah cukup menunjang kedudukan perempuan, khususnya dalam hukum keluarga. Pergeseran zaman dan keadaan yang terus berkembang memposisikan wanita pada posisi yang sama dengan laki-laki. Namun, tawaran tersebut tentunya hanya dapat dipahami bagi kalangan yang berpendidikan. Apalagi dalil-dalil yang dijadikan dasar adalah seumpama HAM dan kesetaraan gender hanya dapat dipahami oleh akademisi, bahkan kalangan masyarakat tertentu tidak tahu akan istilah tersebut. Sepertinya Musdah dan Tim untuk hal tersebut butuh waktu lama untuk bisa memahamkan kepada masyarakat perihal gagasan mereka.

Dilihat dari sebab terjadinya pembaruan hukum keluarga, pertama, ide Musdah mengangkatkan wacana ketiadaan wali dalam rukun nikah, bukanlah bagian dari mengisi kekosongan hukum keluarga di Indonesia, sebab kajian ini sudah lama ada dalam fikih-fikih klasik. Di samping itu, semenjak disahkannya KHI melalui Instruksi Presiden, sudah ada pasal yang mengatur perihal wali yakni wajibnya keberadaan wali sebagai syarat sah pernikahan. Dan kebutuhan masyarakat tentang aturan tentang wali bukanlah perihal yang mendesak, karena aturan yang sudah ada dirasa cukup oleh masyarakat.

Kedua, pengaruh globalisasi dan ilmu pengetahuan dan teknologi tidak dapat dielakkan dalam konteks kehidupan saat ini. Jika dikaitkan dengan tuntutan untuk perubahan pada tatanan hukum keluarga Islam (wali nikah), maka tidak dipungkiri bahwa globalisasi dan ilmu pengetahuan dan teknologi menjadi salah satu pengaruh yang berperan dalam mendorong terjadinya perubahan. Dalam hal wali nikah, yang dulunya ada dalam rangka melindungi perempuan, untuk saat itu sudah tidak sesuai lagi, karena dahulu perempuan kebanyakan berada dirumah maka butuh diawasi oleh orang tua atau walinya, tetapi sekarang sudah banyak perempuan yang berpendidikan tinggi dan mampu mengambil keputusan sendiri. Maka cukup realistis jika Musdah mengambil langkah untuk memperbarui pasal KHI dikarenakan pengaruh globalisasi dan ilmu pengetahuan dan teknologi.

Begitupun pengaruh yang ketiga, pengaruh reformasi diberbagai bidang yang dulunya hanya dikuasai oleh laki-laki, sekarang karena adanya globalisasi perempuan juga bisa masuk kedalam bidang tersebut, bahkan perempuan modern sudah sampai menduduki posisi tertinggi dalam suatu negara. Kondisi zaman modern telah memberikan kesempatan luas bagi perempuan untuk belajar, menimba ilmu dan bekerja serta mengetahui seluk beluk kehidupan masyarakat dan dunia internasional. Oleh karena itu, suatu kewajaran jika Musdah menganggap perempuan saat ini bisa menentukan pilihannya sendiri, tanpa harus didampingi atau diwakili oleh wali dalam pernikahannya.

Pandangan Musdah tampak sejalan dengan pemikiran salah seorang ulama kontemporer, Yusuf al-Qardhawi, bahwa pendapat jumhur yang mengatakan orang tua berhak memaksa anak gadisnya yang sudah baligh untuk menikah dengan calon suami 
pilihan wali mujbir tanpa persetujuan anak, hanya dapat tepat untuk kondisi masa lalu ketika anak perempuan kesulitan mendapatkan akses untuk mengenal calon suaminya. Sementara untuk saat ini sudah tidak relevan lagi. ${ }^{58}$ Kedua pengaruh tersebut, yaitu pengaruh globalisasi dan ilmu pengetahuan dan teknologi serta pengaruh reformasi diberbagai bidang bersesuaian dengan sebab dilakukannya pembaruan hukum keluarga Islam. Kedua hal ini menurut Abdul Manan merupakan aspek umum yang menjadi pengubah hukum, yaitu globalisasi dan perkembangan-perkembangan yang terjadi di bidang sosial, budaya, politik, ekonomi dan pendidikan.

Sementara yang keempat yaitu pengaruh pemikiran mujtabid baik tingkat nasional maupun internasional, tidak ada kesesuaian sebab Musdah tidak mengemukakan keterpengaruhan pemikirannya terhadap tokoh lain, dikarenakan lahirnya pemikirannya adalah murni dari penelitiannya yang mendalam terhadap Alquran dan Sunnah melalui pendekatan keadilan gender. Maka, pengaruh pemikiran mujtahid belum dapat penulis sebut sebagai salah satu faktor yang menyebabkan terjadinya pembaruan dalam konteks pemikiran Musdah tentang wali nikah.

Dari segi metode, pengaruh pemikiran Musdah yang sangat didominasi oleh persoalan kontemporer, maka untuk selanjutnya bentuk metode yang akan dikaji adalah metode kontemporer yaitu melalui pengkajian ulang terhadap nash atau reinterpretasi terhadap persoalan hukum keluarga di Indonesia. Dalam penghapusan wali nikah dari rukun pernikahan, Musdah merujuk kepada apa yang disuarakannya sebagai penghapusan deskriminasi terhadap perempuan dan gender, serta menjunjung sejumlah undang-undang dan konvensi baik ditingkat nasional maupun

58 Asni, "Pembaruan..., 80 internasional yang berhubungan dengan isu-isu yang sama. Sebagaimana bahasan sebelumnya, sebagai seorang pemikir Islam progresif model ijtihad yang dipakai juga berupa pengkajian ulang terhadap hukum, melalui model contextbased ijtibad, sebuah fenomena baru yang mencoba memahami masalah-masalah hukum dalam konteks kesejarahan dan konteks kekiniannya (modern). Pada biasanya, pendapat akhirnya akan mengacu pada kemaslahatan umum sebagai maqasid alsyari' $^{\prime} h^{59}$

Upaya pembaruan yang dilakukan oleh Musdah, mengacu kepada konsep maqashid alsyari"ah. Menurut Musdah pembaruan hukum keluarga Islam dalam bentuk CLD-KHI tetap mengacu kepada sumber hukum Islam yang utama, Alquran dan hadits. Hanya saja pemaknaan terhadap kedua sumber tadi tidak semata kepada pemaknaan literal teks, melainkan lebih banyak kepada pemaknaan non-literal atau kontekstual teks. Adapun pemaknaan kontekstual terhadap tersebut mengacu kepada tujuan syari'at yang terimplementasi dalam nilai-nilai keadilan, kemaslahatan, kebijaksanaan, kesetaraan, kasih sayang dan hak asasi manusia. ${ }^{60}$

Berdasarkan penjelasan di atas, dalam merumuskan konsep tentang ketiadaan wali nikah, metode pembaruan yang dilakukan Musdah tidak terikat kepada pendapatpendapat imam mazhab (ektra-doctrinal reform). Diantara bentuk pembaruan yang menjadi pegangan Musdah adalah reinterpretasi nash yang mendasarkan kepada mashlabah dan penafsiran secara kontekstual (non-litera). Meminjam istilah yang dikemukakan oleh Musdah dalam bukunya bahwa yang dimaksud reinterpretasi adalah murni memenuhi kebutuhan sosiokultural masyarakat tanpa mendasarkan sama sekali terhadap alasan mazhab atau reinterpretasi terhadap teks nash sesuai dengan

${ }^{59}$ Fathurrasyid, Islam ..., 300-301
${ }^{60}$ Siti Musdah Mulia, Islam dan Inspirasi ..., 109 
tuntutan zaman. ${ }^{61}$ Hal ini menjadi bagian dari salah satu metode pembaruan hukum kontemporer (extra-doctrinal reform).

Berangkat dari uraian penulis di atas, dilihat dari segi tujuan dilakukannya pembaruan hukum keluarga Islam, dari tiga aspek terdapat dua aspek yang memiliki relevansi yang cukup kuat dengan pemikiran Musdah mulia tentang ketiadaan wali nikah, yaitu untuk meningkatkan status perempuan dan merespon perkembangan zaman. Dilihat dari segi sebab terjadinya pembaruan hukum keluarga, dari empat aspek terdapat tiga aspek yang bersesuaian, yaitu pengaruh globalisasi dan ilmu pengetahuan dan teknologi serta pengaruh reformasi diberbagai bidang. Dari segi metode Musdah dalam melakukan pembaruan hukum keluarga merujuk kepada konsep kontemporer, dimana metode kontemporer yang ditempuhnya termasuk ke dalam metode pembaruan extra-doctrinal reform, yaitu dengan bentuk reinterpretasi nash. Artinya, dari keseluruhan aspek pembaruan, pemikiran Musdah tentang ketiadaan wali nikah merupakan suatu bentuk pembaruan hukum keluarga Islam. Maka, apa yang diusung oleh Musdah tentang ketiadaan wali dalam rukun nikah sangat perlu untuk dipertimbangkan dalam upaya pembaruan hukum keluarga Islam di Indonesia.

Terlepas dari banyak pandangan Musdah yang dinilai kontroversional, dalam persoalan wali nikah pemikiran Musdah sebenarnya memberikan sebuah semangat pembaruan yang masih layak untuk dilakukan ijtihad terhadap hukum tersebut, hal ini sekaligus menjadi evaluasi bagi hukum tertentu yang memang seharusnya sudah layak untuk dilakukan perubahan, karena pada hakikatnya memang tidak nash yang secara jelas mengatur perihal wajibnya wali dalam pernikahan, bahkan pada para pemikir klasikpun memiliki pandangan yang beragam dalam

\footnotetext{
${ }^{61}$ Ibid., 157
}

merumuskan kedudukannya wali nikah. Menurut Musdah masyarakat sudah terlalu lama terkungkung dizona nyaman pendapat ulama terdahulu, tanpa mau melakukan upaya ijtibad yang lebih sesuai dengan konteks zamannya.

Oleh karena itu, pemikiran Musdah Mulia tentang ketiadaan wali nikah dalam pernikahan merupakan suatu bentuk keberanian dan ketegasan dalam melakukan pembaruan terhadap hukum yang dinilai tidak lagi relevan dengan zaman sekarang. Gagasan Musdah tersebut tidak hanya sekedar pemikiran, akan tetapi Musdah mampu dan berani menempuh jalur legislasi, seperti yang pernah diajukannya pada empat belas tahun yang lampau dan ini juga merupakan bukti bahwa Musdah merupakan salah seorang pemikir (mujaddidab) yang beorientasi melakukan perubahan terhadap hukum yang lebih relevan.

\section{KESIMPULAN}

Berdasarkan pemaparan di atas dapat disimpulkan bahwa pemikiran Musdah Mulia secara umum mengarah kepada tipologi pemikiran Islam liberal. Khusus tentang persoalan ketiadaan wali dalam pernikahan, pemikiran Musdah tidak terlalu bertentangan dengan nash; perhatian Musdah terhadap gender menempatkan porsi yang sangat besar dalam menetapkan hukum tersebut. Ide Musdah tidak hanya disalurkan dalam bentuk pemikiran semata, tetapi juga dituangkan ke dalam bentuk rancangan peraturan hukum (CLD-KHI) agar hukum berlaku menyeluruh dan dapat diaplikasikan secara nyata serta dapat mencapai keadilan dan kemaslahatan sosial di tengah-tengah umat. Maka berdasarkan hal tersebut diperoleh tipologi pemikiran Musdah Mulia khusus tentang ketiadaan wali dalam rukun nikah mengarah kepada pemikiran Islam progresif. 
Jika dilihat dari segi tujuan dilakukannya pembaruan hukum keluarga Islam, segi sebab terjadinya pembaruan hukum keluarga dan dari segi metode pembaruan hukum keluarga penulis berkesimpulan bahwa pemikiran Musdah Mulia tentang ketiadaan wali nikah memiliki relevansi yang cukup dengan pembaruan hukum keluarga Islam di Indonesia. Oleh karena itu, apa yang diusung oleh Musdah tentang ketiadaan wali dalam rukun nikah perlu untuk dipertimbangkan dalam upaya pembaruan hukum keluarga Islam di Indonesia. 


\section{DAFTAR KEPUSTAKAAN}

al-Faifi, Sulaiman, Ringkasan Fikih Sunah, terjemahan dari al-Wajiizu fi Fiqhi al-Sunnab oleh Abdul Majid, Jakarta: Ummul Qura, 2014.

al-Zuhaili, Wahbah, al-Figh al-Islam wa Adillatubu, Jilid VII, Beirut: Dar al-Fikr, 1989.

Az-Zuhaili, Wahbah, Fiqib Islam Jilid 9, terjemahan dari Al-Fiqh Al-Islamiy Wa Adillatubu, oleh Abdul Hayyie al-Kattani, dkk, Jakarta: Gema Insani, 2011.

Bahri, Syaiful, "Kontribusi Pemikiran Qasim Amin dalam Pembaruan Hukum Keluarga Islam”, Al-Ahwal, Vol. 6, no. 1, 2013.

Direktorat Pembinaan Badan Peradilan Agama Islam (DPBPAI), Kompilasi Hukum Islam di Indonesia, Jakarta: DPBPAI, 1997.

Faridah, Anik, "Trend Pemikiran Islam Progresif: Telaah atas Pemikiran Abdullah Saeed", alMabsut: Jurnal Studi Islam dan Sosial, Vo. 7, No. 2, 2013.

Fathurrasyid, "Islam Progresif Versi Abdullah Saeed: Ikhtiar Menghadapi Problem Keagamaan Kontemporer”, al-Ihkam, Vol. 10, No. 2, Desember 2015.

Fuad, Ahmad Masfuful, "Cedaw and The Rights of Kindship in Islamic Family Law", al-Mawarid; Journal of Islamic Law, Vol. XV, No. 1, Agustus 2015.

Hadrianto, Budi, 50 Tokob Islam Liberal Indonesia; Pengusung Ide Sekularisme, Pluralisme dan Liberalisme Agama, Jakarta: Hujjah Press, 2007.

Hamidah, Tutik, Fiqh Perempuan Berwawasan Keadilan Gender, Malang: UIN-Maliki Press, 2011.

Kab'ah, Rifyal, “Kompilasi Hukum Islam Tandingan”, Suara Uldilag, Vol. 11, No. 6. April 2005.

Ma'rifah, Nurul, 'Perkawinan di Indonesia; Aktualisasi Pemikiran Musdah Mulia”, Mabkamah, Vol. 9, No. 1, Januari 2015.

Masthuriya, Sa'dan, 'Perkawinan Beda Agama: Perspektif Islam Progresif”, Kontempelasi, Vol.4, No.2, Desember 2016.

Mulia, Siti Musdah, Islam dan Inspirasi Kesetaraan Gender, Yogyakarta: Kibar Press, 2007.

"Muslim Family Reform In Indonesia: A Progressive Interpretation of The Quran”, al-Mawarid: Joumal of Islamic Law, Vol. XV, No. 1, Agustus 2015.

Pustaka, 2010. Islam dan Hak Asasi Manusia; Konsep dan Implementasi, Yogyakarta: Naufan Kemuliaan Perempuan dalam Islam, Jakarta: PT. Elex Media Komputindo, 2014. "Menuju Hukum Perkawinan yang Adil; Memberdayakan Perempuan Indonesia", dalam buku Sulistyowati Irianto, Perempuan dan Hukum; Menuju Hukum yang Berperspektif Kesetaraan dan Keadilan, Jakarta: Yayasan Obor Indonesia, 2006.

Murti, Ali dan Rahmad Nursyahidin, "Muslim Progresif Omid Safi dan Isu-isu Islam Kontemporer", Jurnal Pendidikan Agama Islam, Vol. 12, No. 2, Desember 2015

Rofiq, Ahmad, Hukum Islam di Indonesia, Jakarta: PT. RajaGrafindo Persada, 2003.

Shafra, Fikih Munakahat I, Bukittinggi: STAIN Bukittinggi Press, 2006.

Sumbulah, Umi, Ketentuan Perkawinan dalam KHI dan Implikasinya bagi Figh Mu'asyarah, Malang: UIN Malang.

Suriansyah, Eka, "Merombak Struktur, Membentuk Kultur; Studi Pemikiran Siti Musdah Mulia”, Jurnal Studi Agama dan Masyarakat, Vol. 13, No. 2, Desember 2017.

Syarifuddin, Amir, Hukum Perkwainan Islam di Indonesia; Antara Fiqh Munakahat dan Undang-Undang Perkawinan Jakarta: Kecana, 2011.

Syaukani, Imam, Rekontruksi Epistimologi Hukum Islam Indonesia dan Relevansinya Bagi Pembangunan Hukum Nasional. Jakarta: PT. Raja Grafindo, 2006.

Tim Sinergi, Tatanan Berkeluarga dalam Islam, Jakarta: Lembaga Kajian Ketahanan Keluarga Indonesia [LK3I], 2015.

Yusdani, “Ushul Fikih dalam Hukum Islam Progresif”, Madania, Vol. 19, No. 1, Juni 2015. 